\title{
Identification phenotypic and genotypic characterization of biofilm formation in Escherichia coli isolated from urinary tract infections and their antibiotics resistance
}

\author{
Elnaz Davari Abad ${ }^{1}$, Amin Khameneh $^{2}$ and Leila Vahedi ${ }^{3^{*}}$ (I)
}

\begin{abstract}
Objective: Urinary tract infections (UTIs) are the most common infectious diseases, and Escherichia coli is the most common pathogen isolated from patients with UTIs. The products of $s f a$, afa and foc genes are important for binding of the bacterium to urinary tract epithelium. Our aim was to investigate these genes in E. colis isolated from patients with UTIS. The frequencies of the genes were determined using PCR. Biofilm formation and antibiotic resistance rates were determined using microtiter plate and disk diffusion methods, respectively. The $P<0.05$ was considered statistically significant.
\end{abstract}

Results: The frequencies of $s f a$, afa and foc were $75.3 \%, 17.5 \%$ and $22.5 \%$, respectively showing a significantly higher prevalence of the sfa gene. The most effective antibiotics against the $E$. colis were nitrofurantoin and amikacin. The highest microbial resistance rates were also observed against amoxicillin and ampicillin. Furthermore, 12.7\%, 6.3\%, $74.7 \%$ and $6.3 \%$ of the isolates showed strong, moderate, weak capacities and no connections to form biofilms, respectively. The expression of the sfa gene was significantly associated with forming strong biofilms. Regarding the variabilities in the characteristics of E. coli strains associated with UTIs, it seems reasonable to adjust diagnostic and therapeutic methods according to the regional microbial characteristics.

Keywords: Escherichia coli, Urinary tract infection, sfa gene, afa gene, foc gene, Biofilm formation, Resistance antibiotics

\section{Introduction}

Urinary tract infections (UTIs) are the most common human infectious disease affecting the bladder, kidneys and urinary tracts [1]. Overall, 150 million people are affected by UTIs worldwide $[2,3]$. The incidence of UTIs is higher in women, and it has been estimated that $40-50 \%$ of adult women experience at least one UTI during their lifespans [1]. Kidney stones, diabetes, weak immune system can increase the risk of UTIs [3].

\footnotetext{
*Correspondence: Vahedi.149@gmail.com

${ }^{3}$ Liver and Gastrointestinal Disease Research Center, Tabriz University of Medical Sciences, Tabriz, Iran

Full list of author information is available at the end of the article
}

Escherichia coli, a Gram-negative bacterium, is responsible for more than $85 \%$ of all UTIs [4].

Biofilm formation ability is one of the important factors increasing the pathogenicity of bacteria and their resistance to antimicrobial agents. Biofilms are communities of microorganisms and their microbial products assisting bacteria to attach to uroepithelial cells. The products of $s f a, a f a$ and $f o c$ genes are particularly involved in these interactions [5]. In fact, the pili (Pap) and s fimbrial adhesion $(s f a)$ which are encoded within the "operon" region of $s f a$ gene confer resistance to uropathogenic bacteria against the host's immune system and a wide range of antibiotics [3].

Particularly, some strains of E. coli called the extended-spectrum beta-lactamases (ESBL), have 
shown resistance to many antibiotics such as ampicillin and tetracycline [4-7]. The identification of these drug resistant microorganisms is essential for choosing proper antibiotics to avoid the waste of time and money and the development of multi-drug resistant bacteria [7, 8].

Polymerase Chain Reactions (PCR) now provides a sensitive and precise method for timely diagnosis of microbial infections. Furthermore, different genotypic and phenotypic detection methods (e.g. microtiter plate assays) are used to evaluate bacterial biofilm formation [6-8]. In the present study, we aimed to investigate the frequencies of $s f a$, afa and $f o c$ genes using PCR in E. coli isolated from patients with UTIs. We also assessed the ability of the isolated bacteria to form biofilms by microtiter plate assay and the tolerance rate of $E$. colis to antibiotics depending on specific genes.

\section{Main text}

\section{Methods}

\section{Patients and collecting samples}

This research was a cross-sectional research where 150 urine samples were gathered from patients with the symptoms of urinary tract infection who had been admitted at Amir Almomenin's Hospital, Central Laboratory of the University of Medical Sciences, and Private and Medical Dinesh's Laboratory through census method in Maragheh/Iran in 2018. To confirm infection with $E$. coli, the samples were cultured in the microbiology section in the EMB Agar and Blood Agar and were identified by the Gram, Indole, Citrate and MR-VP tests. Duplicate patient samples were excluded from this study. Finally, 79 samples for $E$. coli were recognized. The laboratory criteria of acute urinary tract infection with $E$. coli included one positive culture of colonies with a minimum number of $10^{5}$ colonies per $1 \mathrm{ml}$ of urine [9]. This study was conducted on Azeri Turks, who are members of one of the largest ethnic groups in Iran [10].

\section{Genotypic study}

DNA extraction In the current study, the boiling method was used for DNA extraction from the urine samples [11]. Specifically, several fresh bacteria colonies were mixed in $200 \mu$ lof buffer TE (Tris HCL $10 \mathrm{Mm}+$ EDTA $1 \mathrm{Mm}$ ). Then, some water was boiled and after reaching the boiling point, the above sample was placed on a piece of unileet placed on the surface of water for boiling over $10 \mathrm{~min}$. Finally, the sample was centrifuged at 10,000 rpm for $10 \mathrm{~min}$ and upper liquid was used for PCR.

$P C R$ reaction Specific primers were used to amplify the sequences of the $s f a, a f a$, and $f o c$ genes $[12,13]$ (Table 1). As indicated in Table 1, the PCR assay was carried out in a total volume of $25 \mu \mathrm{l}$ of mixture containing $22 \mu \mathrm{l}$ master mix, $1 \mu$ l DNA sample, $1 \mu$ l forward primer, $1 \mu$ reverse primer, and $0.2 \mu \mathrm{l} \mathrm{tag}$ polymerase. The PCR timetable program for $s f a, a f a$, and $f o c$ genes is presented in Table 1.

Once analyzed by $2 \%$ agarose gel electrophoresis, the PCR products were stained with ethidium bromide and photographed.

Assessment of biofilm formation via phenotype method For investigating the ability of $E$. coli isolates to produce biofilms, biofilm test was performed in laboratory based on the Microtiter Plates Assay as follow as:

The microtiter plate method was used for evaluating the formation of UPEC biofilm. The Microtiter Plates Assay method, such as ELISA, the color-producing chromogen in this technique is fuchsin, whose color intensity is directly related to the concentration of biofilm.

Table 1 Primers and PCR timetable program for sfa, afa, and foc genes in UPEC strain

\begin{tabular}{|c|c|c|c|c|c|c|c|c|}
\hline Genes & Initial cycle & Denaturation & Annealing & Extension & Final extension & Primers sequencing & & $\begin{array}{l}\text { Product } \\
\text { size (bp) }\end{array}$ \\
\hline \multicolumn{9}{|l|}{ sfa gene } \\
\hline Time & $4 M$ & $30 \mathrm{~S}$ & $30 M$ & $40 S$ & $3 M$ & \multirow{3}{*}{$\begin{array}{l}F: 5^{\prime} C C G T A A G \\
\text { ATGTCTGCG } \\
\text { A G } 3^{\prime}\end{array}$} & \multirow{4}{*}{$\begin{array}{l}\mathrm{R}: 5^{\prime} A G C A A G T C \\
\text { T G GCAACG } \\
\text { A G } 3^{\prime}\end{array}$} & \multirow[t]{3}{*}{100} \\
\hline Temperature & 95 & 95 & 53 & 72 & 72 & & & \\
\hline Number of cycles & 1 & 35 & 35 & 35 & 1 & & & \\
\hline \multicolumn{8}{|l|}{ afa gene } & \\
\hline Time & $5 \mathrm{M}$ & $1 \mathrm{~S}$ & $30 M$ & $3 S$ & $7 \mathrm{M}$ & \multirow{3}{*}{ 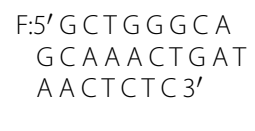 } & \multirow{3}{*}{$\begin{array}{c}\mathrm{R}: 5^{\prime} C A T C A A G C T \\
\text { GTTTGTTCGT } \\
\text { C C GCCG } 3^{\prime}\end{array}$} & \multirow[t]{3}{*}{750} \\
\hline Temperature & 95 & 95 & 60 & 72 & 72 & & & \\
\hline Number of cycles & 1 & 35 & 35 & 35 & 1 & & & \\
\hline \multicolumn{9}{|l|}{ foc gene } \\
\hline Time & $4 M$ & $1 \mathrm{~S}$ & $1 \mathrm{M}$ & $2 S$ & $10 \mathrm{M}$ & \multirow{3}{*}{$\begin{aligned} F: 5^{\prime} G G T G G A A C \\
C G C A G A A A A \\
\text { TAC } 3^{\prime}\end{aligned}$} & \multirow{3}{*}{$\begin{array}{l}\mathrm{R}: 5^{\prime} \mathrm{G} A \mathrm{~A} C \mathrm{~T} \mathrm{GTTG} \\
\text { G G GAAAGAG } \\
\text { TG } 3^{\prime}\end{array}$} & \multirow[t]{3}{*}{388} \\
\hline Temperature & 95 & 95 & 58 & 72 & 72 & & & \\
\hline Number of cycles & 1 & 35 & 35 & 35 & 1 & & & \\
\hline
\end{tabular}


Initially, one loop full of bacteria colony was infused into one tube, including $5 \mathrm{ml}$ nutrient broth where this tube was heated at $37^{\circ} \mathrm{C}$ for 18 to $24 \mathrm{~h}$. Then, $1 \mathrm{ml}$ of bacterial suspension was injected into the tube, including $10 \mathrm{ml}$ sterile nutrient broth, with this tube being heated at $37^{\circ} \mathrm{C}$ for a duration of 18 to $24 \mathrm{~h}$. Regarding the injection only the sterile culture environment of nutrient broth into control well, microtiter plate was heated at $37^{\circ} \mathrm{C}$ for $24 \mathrm{~h}$. After the draining and washing of the wells three times by a sterile physiology serum, the plates were vigorously shaken to eliminate the disconnected cells. For stabilizing the cells, $200 \mu \mathrm{l}$ ethanol $96 \%$ was added to wells. After $15 \mathrm{~min}$, the wells were drained, dried and stained by $200 \mu \mathrm{l}$ fuchsin for $5 \mathrm{~min}$. After $5 \mathrm{~min}$, the wells were washed slowly by urban water and were filled with $200 \mu \mathrm{L}$ acetic acid $33 \%$ as solvent. After plate incubation for $15 \mathrm{~min}$ at $37^{\circ} \mathrm{C}$, the Optical Density of the wells stained with fuchsin was screened by ELISA at a wavelength $492 \mathrm{~nm}$. All measurements were repeated three times and the culture environment was used as negative control. A standard deviation larger than the negative control optical absorption was used as Cut-off. The ability of biofilm formation was calculated using the following formulas [14] that shown in the table. In the current study, $\mathrm{OD} \geq 0.1,0.07 \leq \mathrm{OD} \leq 0.09,0.01 \leq \mathrm{OD} \leq 0.06$ and $\mathrm{OD} \leq 0.009$ were considered strong, average, weak and no connection, respectively.

Assessment of antibiotic resistance in E. coli The antibiotic sensitivity was examined by Kirby Beuer method (disk diffusion) [14]. The diameter of the zones of inhibition was measured by a ruler in millimeter. In this research, the antibiotics utilized against $E$. coli pathogens included Imipenem, Ciprofloxacin (cp5), Tobramycin (TOB10), Ampicillin, Tetracycline (TE30), Amikacin (AN30), Amoxicillin (AMX25), Nalidixic Acid (NA30), Nitrofurantoin, Cefepime, Gentamycin (GM10), Ceftazidime (CAZ30), Chloramphenicol, and Ceftriaxone (CRO30).

\section{Data analysis}

Data were analyzed using SPSS 23 for the frequency and percentage. The comparison between variables was analyzed by a Chi square or Fisher's exact tests. $P<0.05$ was considered statistically significant.

\section{Results}

In this study, the PCR reaction was done on 79 samples from urine specimens with UTI symptoms and suspected to have E. coli, after confirmation (Additional file 1: Fig. S1).

The PCR results indicated that the highest and lowest frequency of fimbrial genes was associated with $s f a$ and $s f a-a f a-f o c$ genes (Table 2). Then, the frequency of $s f a$ gene was compared to other genes. There was a significant difference between $s f a$ with $a f a, f o c, s f a-a f a, s f a-f o c$, $a f a-f o c$, and sfa-afa-foc with 0.04, 0.001, 0.009, 0.001 and 0.00 P-values, respectively.

\section{Results of microtiter plate biofilm formation}

Among $79 \mathrm{E}$. coli isolates from urinary tract infections, 10 isolates (12.7\%), 5 isolates $(6.3 \%), 59$ isolates $(74.7 \%)$ and 5 isolates $(6.3 \%)$ showed strong, moderate, weakly and no connection biofilm formation ability, respectively.

The capacity of biofilm formation were compared between genes, where there was no significant correlation between them; however, the strongest and the weakest had related to $s f a$ and $a f a$ genes, respectively (Table 2). Of note, afa even has reduced ability of biofilm formation in combination with other genes.

In the antibiotic resistance, the most resistant strains were related to the amoxicillin and ampicillin antibiotics, while the greatest sensitivity was associated with nitrofurantoin and amikacin (Tables 2 and 3).

\section{Discussion}

E. coli is the most common causative agent of UTIs in both outpatients and inpatients. If left untreated, UTIs may culminate in serious consequences such as renal failure. Pyelonephritis usually develops following a simple bladder infection (i.e. cystitis) [5]. The ability of pathogenic bacteria to adhere to the urinary tract epithelium using pili (fimbriae) is the most important pathogenic feature leading to UTIs [15]. Various genes encoding pili can be identified by molecular techniques such as PCR [16].

Our results revealed a relatively high frequency of $s f a$ gene compared with the afa and foc in E. coli strains isolated from patients with UTIs. This probably indicates the essential role of this gene in the development of UTIs. Various studies have reported the role of $s f a$ gene in encoding adherence molecules involved in the pathophysiology of pyelonephritis caused by E. coli [3]. In line with our finding, Jalali et al. [17] reported that $32 \%$ of UTIs patients expressed the sfa gene. In another study among children suffering from UTI caused by E. coli, a high frequency of the sfa gene was reported [18]. Likewise, the frequency of the afa gene reported in another study was similar to the present report [19].

In the present study, strong and weak biofilm-forming capabilities were associated with the expressions of the $s f a$ and $a f a$ genes, respectively. Reduction of biofilm formation ability was observed in combination of afa gene with other genes.

According to a study conducted by Lane MC et al., fimbria I molecule is upregulated during UTIs to ensure bacterial motility. This phenomenon is particularly 


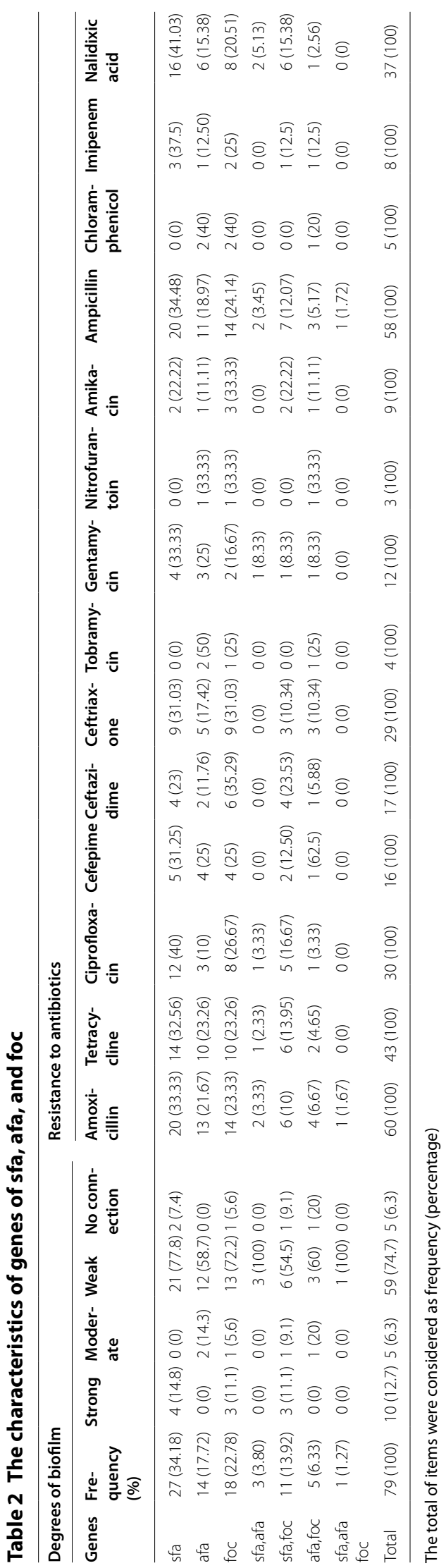


Table 3 Results of antibiogram for genes of UPEC strain

\begin{tabular}{lccl}
\hline Antibiotics & Resistant* & Intermediate* & Sensitive* \\
\hline Amoxicillin & $60(18.13)$ & $4(2.21)$ & $15(2.53)$ \\
Tetracycline & $43(12.99)$ & $9(4.97)$ & $27(4.55)$ \\
Ciprofloxacin & $30(9.06)$ & $9(4.97)$ & $40(6.73)$ \\
Sefipem & $16(4.83)$ & $15(8.29)$ & $48(8.08)$ \\
Ceftazidime & $17(5.14)$ & $7(3.87)$ & $55(9.26)$ \\
Ceftriaxone & $29(8.79)$ & $7(3.87)$ & $43(7.24)$ \\
Tobramycin & $4(1.21)$ & $28(15.47)$ & $47(7.91)$ \\
Gentamicin & $12(3.63)$ & $14(7.73)$ & $53(8.92)$ \\
Nitrofurantoin & $3(0.91)$ & $7(3.87)$ & $69(11.62)$ \\
Amikacin & $9(2.72)$ & $30(16.57)$ & $40(6.73)$ \\
Ampicillin & $58(17.52)$ & $10(5.52)$ & $11(1.85)$ \\
Chloramphenicol & $5(1.51)$ & $8(4.42)$ & $66(11.11)$ \\
Imipenem & $8(2.42)$ & $25(13.81)$ & $46(7.74)$ \\
Nalidixic Acid & $37(11.18)$ & $8(4.42)$ & $34(5.72)$ \\
\hline
\end{tabular}

*The total of items were considered as frequency (percentage)

important during $24 \mathrm{~h}$ after the colonization of bacteria in the bladder [20]. In another study, Goetz et al. [21] described the role of pap $G$ gene in augmenting the ability of bacteria to connect to surfaces. In the report of Ponnusamy et al. [22], only $23.6 \%$ of $E$. coli strains were able to from strong biofilms. These reports highlight the roles of $P$ fimbriae (pap), afa, hemolysin (hly), and $s f a / f o c$ in biofilm formation by bacteria causing human infections. These molecules help bacteria to colonize and damage tissues and debilitate the host's defense mechanisms which ultimately lead to clinical manifestations [23].

In the present study, the highest resistance rates of the isolated $E$. coli strains were observed against amoxicillin and ampicillin. This was while the greatest sensitivities were related to nitrofurantoin and amikacin antibiotics. In the study of Gazmoh et al. in Ethiopia, Adimi et al. in Nigeria and Abdollahi et al. in Tehran, E. coli strains from patients with UTIs demonstrated a similar resistance pattern to the present study [24-26].

Escherichia coli is considered as an important cause of UTI in patients referring to health centers. The severity of the infection depends on both the host's immune competency and the distribution of virulence factors among pathogenic bacteria. UPEC isolates are genetically heterogeneous bacteria which have variable capacities for biofilm formation, colonization, invasion, and proliferation in the urinary tract $[27,28]$.

In another study by Jha et al. [29] on 244 patients with UTIs in Japan, E. coli was reported as the most frequent causative agent, and the least resistance rate was related to ciprofloxacin. In contrary to our results; however, Keikha et al. [30] in their study on 87 urinary E. coli isolates reported the highest antibiotic resistance against cotrimoxazole. These inconsistencies can be related to parameters such as sample sizes, the accuracies of sampling and testing methods, as well as different geographical locations [27-30].

Generally, E. coli strains causing UTIs represent increasing rates of antibiotic resistance, especially against the first (e.g. ampicillin) [31] the third (e.g. cephalosporins and aminoglycosides) generations of broad-spectrum antibiotics [32]. These high rates of antibiotic resistance may be due to the unprescribed availability and uncontrolled usage of antibiotics, especially in developing countries. Therefore, selecting antibiotics for treating bacterial infections should be according to the results of urine culture, antibiotic susceptibility, and biofilm formation analyses.

\section{Conclusion}

There were differences between the characteristics of UPEC in this area and different regions in terms of frequency, formation of biofilm, and drug resistance. These differences were even observed among strains. By collecting the characteristics of UPEC strains in each region, the epidemiological characteristics of native isolates were distinguished. Therefore, it is possible to diagnose this condition earlier and offer appropriate treatments.

\section{Limitation}

This study was limited by short duration and moderate sample. Ultimately, it is recommended to performing of the other studies on other genes between control and case groups.

\section{Supplementary information}

Supplementary information accompanies this paper at https://doi. org/10.1186/s13104-019-4825-8.

Additional file 1: Fig S1. Escherichia coli strains including of sfa, afa and foc genes on agarose gel.

\section{Abbreviations}

E. coli: Escherichia coli; UTIs: urinary tract infections; UPEC: uropathogenic Escherichia Coli; Pap: pyelonephritis associated pili; sfa: s fimbrial adhesion; OD: optical density; NM: nanometer; $\mu \mathrm{L}$ : microliter; ML: milliliter; C: centigrade.

\section{Acknowledgements}

We would like to thank staffs of Amir Almomenin's Hospital, Central Laboratory of the University of Medical Sciences and Private and Medical Dinesh's Laboratory in Maragheh/Iran that corporate in the progression this study.

\section{Authors' contributions}

ED and LV: conceived the study. ED: participated in the acquisition of data and sampling. ED and LV: participated in the design of the study and performed the statistical analysis. LV: interpreted the data. ED: obtained ethical clearance and permission for study. ED: performing tests. ED and AK: preparing image. ED and AK: preparing tables. LV, ED and AK: Drafting the article or revisiting it critically for important intellectual content. LV and AK: manuscript submitting. 
LV, ED and AK: manuscript revising. AK: English editing. All authors read and approved the final manuscript.

\section{Funding}

Not applicable.

\section{Availability of data and materials}

The datasets used and analyzed during the current study are available from the corresponding author and first author on not allowed from the centers. Private and Medical Dinesh's Laboratory in Maragheh and Liver and Gastrointestinal Disease Research Center of Tabriz University of Medical Sciences are where supporting our findings.

\section{Ethics approval and consent to participate}

This study was approved by the Ethics Committee of the Islamic azad University, Urmia, Iran (NO = 10330507942022). The participation in the research was voluntary the following informed consent obtained from the patients as written and that they will be free to discontinue participation.

\section{Consent for publication}

Not applicable.

\section{Competing interests}

The authors declare that they have no competing interests.

\section{Author details}

${ }^{1}$ Department Of Microbiology, Faculty of Basic Science, Islamic Azad University, Urmia, Iran. ${ }^{2}$ Student of Medicine, Faculty of Medicine, Tabriz University of Medical Sciences, Tabriz, Iran. ${ }^{3}$ Liver and Gastrointestinal Disease Research Center, Tabriz University of Medical Sciences, Tabriz, Iran.

Received: 9 August 2019 Accepted: 26 November 2019

Published online: 05 December 2019

\section{References}

1. Tarchouna M, Ferjani A, Ben-Selma W, Boukadida J. Distribution of uropathogenic virulence genes in Escherichia coli isolated from patients with urinary tract infection. Int J Infect Dis. 2013;17(6):e450-e3. https:// doi.org/10.1016/j.ijid.2013.01.025.

2. Sahib AS, Mohammed IH, Hamdan SJ. Use of aqueous extract of corn silk in the treatment of urinary tract infection. J Complement Med Res. 2012;1(2):93-6. https://doi.org/10.5455/jice.20120525123150.

3. Emody L, Kerenyi M, Nagy G. Virulence factors of uropathogenic Escherichia coli. Int J Antimicrob Agents. 2003;22:29-33. https://doi.org/10.1016/ S0924-8579(03)00236-X.

4. Oloketuyi SF, Khan F. Strategies for biofilm inhibition and virulence attenuation of foodborne pathogen-Escherichia coli O157: H7. Curr Microbiol. 2017;74(12):1477-89. https://doi.org/10.1007/s00284-017-1314-y.

5. Lee J, Subhadra B, Son YJ, Kim D, Park H, Kim J, et al. Phylogenetic group distributions, virulence factors and antimicrobial resistance properties of uropathogenic Escherichia coli strains isolated from patients with urinary tract infections in South Korea. Appl Microbiol. 2016;62(1):84-90. https:// doi.org/10.1111/lam.12517.

6. Brandström P, Hansson S. Long-term, low-dose prophylaxis against urinary tract infections in young children. Pediatr Nephrol. 2015;30(3):42532. https://doi.org/10.1007/s00467-014-2854-z.

7. Qu Y, Li R, Jiang M, Wang X. Sucralose increases antimicrobial resistance and stimulates recovery of Escherichia coli mutants. Curr Microbiol. 2017;74(7):885-8. https://doi.org/10.1007/s00284-017-1255-5.

8. Bryce A, Hay AD, Lane IF, Thornton HV, Wootton M, Costelloe C. Global prevalence of antibiotic resistance in paediatric urinary tract infections caused by Escherichia coli and association with routine use of antibiotics in primary care: systematic review and meta-analysis. BMJ. 2016;352:1939. https://doi.org/10.1136/bmj.i939.

9. Terlizzi ME, Gribaudo G, Maffei M. UroPathogenic Escherichia coli (UPEC) infections: virulence factors, bladder responses, antibiotic, and nonantibiotic antimicrobial strategies. Front Microbiol. 2017;8:1566. https:// doi.org/10.3389/fmicb.2017.01566.
10. Vahedi L, Jabarpoor-Bonyadi M, Ghojazadeh M, Hazrati H, Rafeey M. Association between outcomes and demographic factors in an Azeri Turkish population with cystic fibrosis: a cross-sectional study in Iran from 2001 through 2014. IRCMJ. 2016. https://doi.org/10.5812/ircmj.29615.

11. Shan Z, Zhou Z, Chen H, Zhang Z, Zhou Y, Wen A, et al. PCR-ready human DNA extraction from urine samples using magnetic nanoparticles. J Chromatogr. 2012;881:63-8. https://doi.org/10.1016/j.jchro mb.2011.11.042.

12. Gilbert NM, Lewis AL. Covert pathogenesis: transient exposures to microbes as triggers of disease. PLoS Pathog. 2019;15(3):e1007586. https ://doi.org/10.1371/journal.ppat.1007586.

13. Malekzadegan Y, Khashei R, Ebrahim-Saraie HS, Jahanabadi Z. Distribution of virulence genes and their association with antimicrobial resistance among uropathogenic Escherichia coli isolates from Iranian patients. BMC Infect Dis. 2018;18(1):572. https://doi.org/10.1186/s12879-018-3467-0.

14. Nourbakhsh F, Momtaz H. Evaluation of phenotypic and genotypic biofilm formation in Staphylococcus aureus isolates isolated from hospital infections in Shahrekord, 2015. Evaluation. 2016;19(109):69-79 (In Persian).

15. Bahalo S, Tajbakhsh E, Tajbakhsh S, Momeni M, Tajbakhsh F. Detection of some virulence factors of Escherichia coli isolated from urinary tract infection isolated of children in Shahrekord Iran by multiplex PCR. Middle East J Sci Res. 2013;14(1):29-32.

16. Yazdi M, Bouzari M, Ghaemi EA. Detection of fim, pap, sfa and afa adhesin-encoding operons in Escherichia coli strains isolated from urinary tract infections. Mod Med Lab. 2018;12(5):10-5. http://mlj.goums.ac.ir/ article-1-1114-en.html.

17. Jalali HR, Pourbakhsh A, Fallah F, Eslami G. Genotyping of virulence factors of uropathogenic Escherichia coli by PCR. Novel Biomed. 2015;3(4):177-81.

18. Abana CO, Bingham BS, Cho JH, Graves AJ, Koyama T, Pilarski RT, et al. IL-6 variant is associated with metastasis in breast cancer patients. PLOS ONE. 2017;12(7):e0181725. https://doi.org/10.1371/journal.pone.0181725.

19. Yun KW, Kim HY, Park HK, Kim W, Lim IS. Virulence factors of uropathogenic Escherichia coli of urinary tract infections and asymptomatic bacteriuria in children. J Microbiol Immunol Infect. 2014;47(6):455-61. https:// doi.org/10.1016/j.jmii.2013.07.010.

20. Lane MC, Simms AN, Mobley HL. Complex interplay between type 1 fimbrial expression and flagellum-mediated motility of uropathogenic Escherichia coli. J Bacteriol. 2007;189(15):5523-33. https://doi. org/10.1128/jb.00434-07.

21. Goetz G, Mahmood A, Hultgren S, Engle M, Dodson K, Alpers DJl, et al. Binding of Pili from Uropathogenic Escherichia coli to membranes secreted by human colonocytes and enterocytes. Infect Immun. 1999;67(11):6161-3.

22. Ponnusamy P, Natarajan V, Sevanan MJ. In vitro biofilm formation by uropathogenic Escherichia coli and their antimicrobial susceptibility pattern. Asian Pac J Trop Med. 2012;5(3):210-3. https://doi.org/10.1016/ S1995-7645(12)60026-1.

23. Tajbakhsh E, Ahmadi P, Abedpour-Dehkordi E, Arbab-Soleimani N, Khamesipour F. Biofilm formation, antimicrobial susceptibility, serogroups and virulence genes of uropathogenic E. coli isolated from clinical samples in Iran. Antimicrob Resist Infect Control. 2016;5:1. https://doi. org/10.1186/s13756-016-0109-4.

24. Adeyemi AO, Evbaziegbere Gideon E, Eromosele IH, Evelyn Chimerenma A, Sunday Oladokun O, Eunice Ogochukwu U, et al. Antibiotics susceptibility patterns of some uropathogens to nitrofurantoin and nalidixic acid among pregnant women with urinary tract infections in federal medical centre, Bida, Niger-State, North Central, Nigeria. Am J Epidemiol. 2014;2(4):88-92. https://doi.org/10.12691/ajeid-2-4-1.

25. Abdolahi AR, Mehr Azma M. Evaluation of antibiotic susceptibility and resistance in urinary infections, Imam Khomeini Hospital, Tehran. J Jahrom Univ Med Sci. 2009;7(9):59-66.

26. Gezmu T, Regassa B, Manilal A, et al. Prevalence, diversity and antimicrobial resistance of bacteria isolated from the UTI parents of Arba Minch Province, Southern Ethiopia. Transl Biomed. 2016;7:3. https://doi. org/10.21767/2172-0479.100081.

27. Kumarasamy KK, Toleman MA, Walsh TR, Bagaria J, Butt F, Balakrishnan $\mathrm{R}$, et al. Emergence of a new antibiotic resistance mechanism in India, Pakistan, and the UK: a molecular, biological, and epidemiological study. 
Lancet Infect Dis. 2010;10(9):597-602. https://doi.org/10.1016/S1473 -3099(10)70143-2.

28. Karlowsky JA, Kelly LJ, Thornsberry C, Jones ME, Sahm DF. Trends in antimicrobial resistance among urinary tract infection isolates of Escherichia coli from female outpatients in the United States. Antimicrob Agents Chemother. 2002;46(8):2540-5. https://doi.org/10.1128/ AAC.46.8.2540-2545.2002.

29. Jha N, Bapat SJ. A study of sensitivity and resistance of pathogenic micro organisms causing UTI in Kathmandu valley. KUMJ. 2005:3(2):123-9.

30. Keikha M, Rava M. Evaluation of antibiotic resistance of Escherichia coli strains isolated from urinary tract infections in outpatients referring to Nabi Akram Hospital in Zahedan. J Paramed Sci Rehabilit. 2017;6(4):73-8.
31. Jan N, Meshram SU, Kulkarni A. Plasmid profile analysis of multidrug resistant E. coli isolated from UTI patients of Nagpur city, India. Rom Biotechnol Lett. 2009;14(5):4635-40.

32. Novakova I, Kacaniova M, Hascik P, Pavlicova S, Hleba L. The resistance to antibiotics in strains of $E$. coli and enterococcus sp. isolated from rectal swabs of lambs and calves. Lucrari Stiintifice Zootehnie Sibiotehnologii. 2009;42(2):322-6

\section{Publisher's Note}

Springer Nature remains neutral with regard to jurisdictional claims in published maps and institutional affiliations. 